\title{
Effects of endotoxin lipopolysaccharide administration on the somatotropic axis
}

\author{
L Soto, A I Martín², S Millán, E Vara ${ }^{1}$ and A López-Calderón \\ Departamento de Fisiología and ${ }^{1}$ Departamento de Bioquímica, Facultad de Medicina, Universidad Complutense, Madrid, Spain and ${ }^{2}$ Departamento CC \\ Morfológicas y Fisiología, Universidad Europea, Madrid, Spain \\ (Requests for offprints should be addressed to A López-Calderón, Departamento de Fisiología, Facultad de Medicina, Universidad Complutense, \\ 28040 Madrid, Spain)
}

\begin{abstract}
The aim of this work was to study the effect of chronic activation of the immune system on the somatotropic axis. Accordingly, the changes in growth hormone $(\mathrm{GH})$ secretion, circulating insulin-like growth factor-I (IGF-I) and IGF binding proteins (IGFBPs) in response to endotoxin lipopolysaccharide (LPS) administration were examined in adult male Wistar rats. Acute LPS injection $(2 \cdot 5,25$ or $250 \mu \mathrm{g} / \mathrm{kg}$ ) increased serum corticosterone in a dosedependent manner and decreased serum levels of insulin and IGF-I, serum GH concentration declined linearly as the LPS dose increased. Western ligand blot showed an increase in the $33 \mathrm{kDa}$ band (corresponding to IGFBP-1 and IGFBP-2) in the rats that received the highest dose of
\end{abstract}

LPS $(250 \mu \mathrm{g} / \mathrm{kg})$. Chronic LPS administration $(250 \mu \mathrm{g} / \mathrm{kg}$ daily for 8 days) significantly decreased body weight, serum levels of IGF-I and pituitary GH content, whereas it increased circulating IGFBP-3 (47 kDa band), IGFBP-1 and IGFBP-2 (33 kDa band) and the $24 \mathrm{kDa}$ band (which possibly corresponds to IGFBP-4). Serum concentration of corticosterone and hypothalamic somatostatin content were also increased by chronic LPS treatment. These data suggest that the decrease in GH and IGF-I secretion and the increase in circulating IGFBPs are important mechanisms in body weight loss during chronic inflammation.

Journal of Endocrinology (1998) 159, 239-246

\section{Introduction}

It is well known that the immune and the neuroendocrine systems communicate bidirectionally. Hormones modulate the immune system, and in turn, cytokines, the soluble factors secreted by the immune cells, modify the neuroendocrine secretion (for reviews see Madden \& Felten 1995, Besedovsky \& Del Rey 1996). Acute infection induces adrenal hypertrophy (Pinchot et al. 1949) and immunization with sheep red blood cells activates the hypothalamic-pituitary-adrenal axis (Besedovsky et al. 1975). These effects seem to be mediated by the released cytokines, and it has been shown that interleukin (IL)-1, IL-2, IL-6 and $\gamma$-interferon increase glucocorticoid secretion (Besedovsky \& Del Rey 1996).

However, immunostimulation not only activates the adrenal axis, but also modifies other hormones. Acute endotoxin administration in rats increases plasma concentration of corticosterone whereas it decreases circulating growth hormone $(\mathrm{GH})$ and insulin-like growth factor-I (IGF-I) (Egdahl 1959, Kastin \& Martin 1982, Fan et al. 1994). In humans, growth retardation has been described in children suffering from chronic infectious illnesses (McCaffery et al. 1970). A decrease in serum concentration of IGF-I in septic patients has also been observed
(Dahn et al. 1988). However, the effect of cytokines on GH secretion is not well known. IL-1 administration has been reported both to increase (Rettori et al. 1987) and decrease (Peisen et al. 1995) GH secretion. Similarly, tumor necrosis factor- $\alpha$ (TNF $\alpha$ ) has also been reported to increase (Rettori et al. 1989, Elsasser et al. 1991) and decrease (Walton \& Cronin 1989) GH secretion. Thus, several mechanisms by which chronic immune activation decreases circulating IGF-I have been hypothesized: increased glucocorticoid secretion, decreased GH secretion and $\mathrm{GH}$ resistance.

The aim of this work was to analyze the effect of chronic inflammation on the somatotropic axis. We studied the effect of lipopolysaccharide (LPS) on IGF-I and $\mathrm{GH}$ secretion as important components of the somatotropic axis. Since IGF-I action can be modulated by changes in the IGF-binding proteins (IGFBPs), which can increase or inhibit the IGF-I effects, we also analyzed serum IGFBPs. Serum concentrations of corticosterone and insulin were determined.

\section{Materials and Methods}

Adult male Wistar rats weighing 250-300 g were obtained from Charles River (Barcelona, Spain) and maintained 

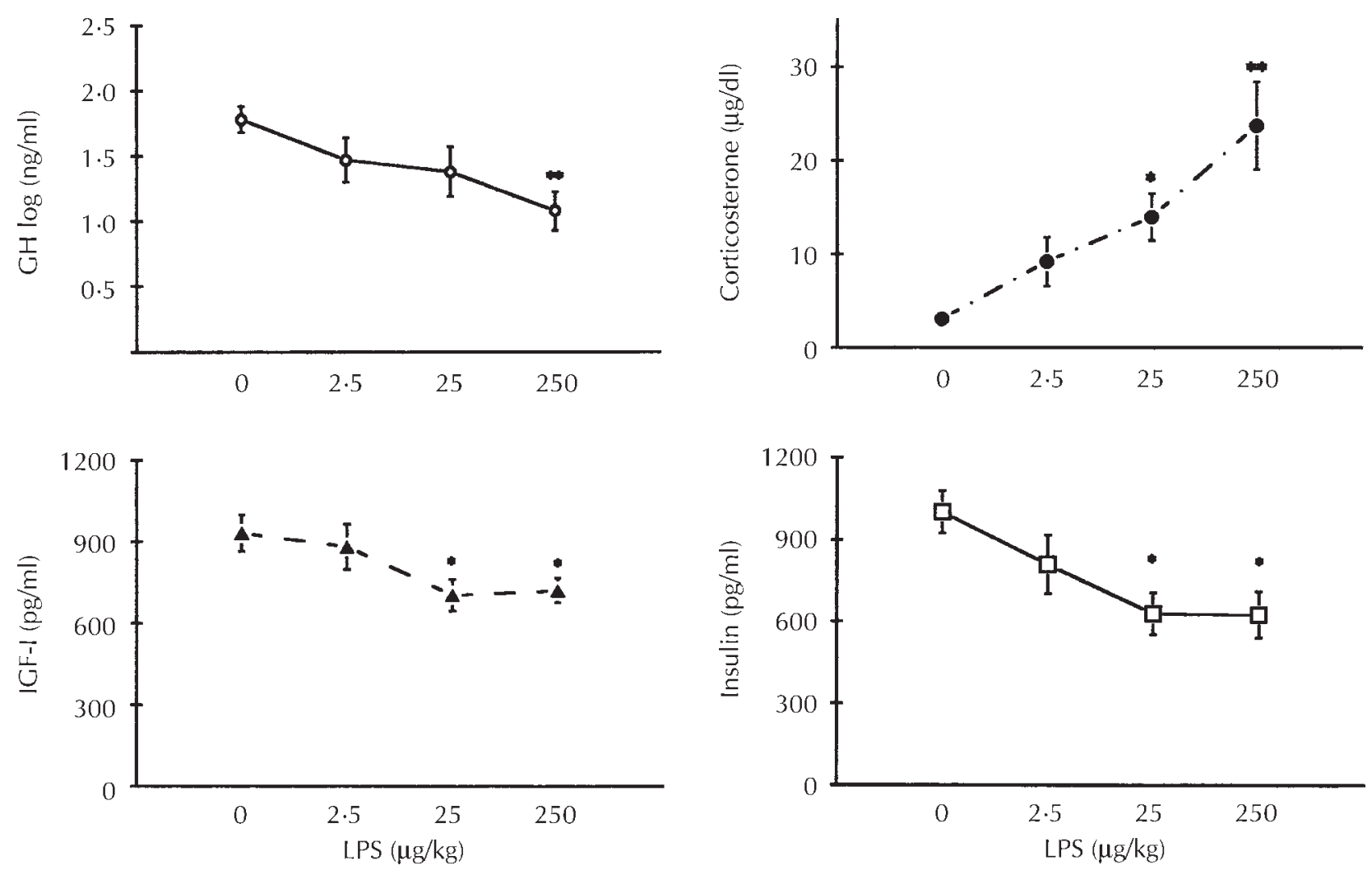

Figure 1 Changes in serum concentrations of GH and IGF-I three hours after an injection of varying doses of LPS. Each point represents the mean \pm S.E.M. for at least 9 rats per group. ${ }^{*} P<0 \cdot 05$, ${ }^{* *} P<0 \cdot 01$ vs control group (Duncan's multiple range test).

under controlled temperature $\left(20-22{ }^{\circ} \mathrm{C}\right)$ and light conditions (lights on from 0730 to $1930 \mathrm{~h}$ ). Food and water were available ad libitum. The rats were used at least 8 days after arrival. The procedures followed the guidelines recommended by the European Union for the care and use of laboratory animals.

\section{Acute LPS administration}

The animals were injected with $0,2 \cdot 5,25$ or $250 \mu \mathrm{g} / \mathrm{kg}$ LPS (serotype 055:B5; Sigma Chemical Co., St Louis, MO, USA) in $250 \mu \mathrm{l}$ saline i.p. at $1000 \mathrm{~h}$. Acute LPS administration induces transient hypotension and hyperglycemia which disappear at $3 \mathrm{~h}$ (Virkamaki \& Yki-Jörvinen 1994); therefore, $3 \mathrm{~h}$ after LPS injection the rats were killed by decapitation and trunk blood was collected in tubes at $4{ }^{\circ} \mathrm{C}$. The blood was allowed to clot, centrifuged and the serum was stored at $-20^{\circ} \mathrm{C}$ until $\mathrm{GH}$, IGF-I, IGFBPs, insulin and corticosterone assays were performed. Immediately after decapitation the pituitary gland was removed and stored at $-20{ }^{\circ} \mathrm{C}$ for $\mathrm{GH}$ assay. The medial basal hypothalami were dissected as previously described (López-Calderón et al. 1990) and

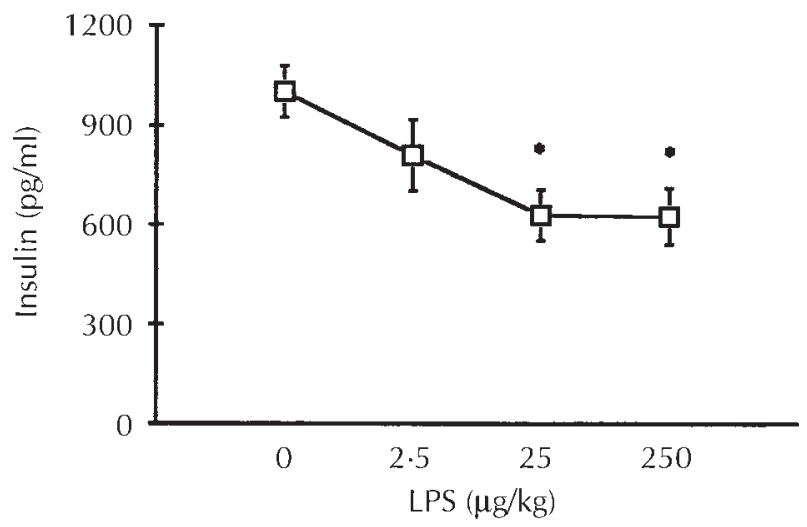

Figure 2 Effect of a single LPS injection at different doses on serum levels of corticosterone and insulin. Each point represents the mean \pm S.E.M. for at least 6 rats per group. ${ }^{*} P<0 \cdot 05,{ }^{* *} P<0.01$ vs control group (Duncan's multiple range test).

quickly frozen in a dry-ice/acetone mixture and stored at $-80{ }^{\circ} \mathrm{C}$ until the somatostatin assay was carried out.

\section{Chronic LPS}

Rats were injected i.p. once daily for 8 days with 0 or $250 \mu \mathrm{l} / \mathrm{kg}$ LPS in $250 \mu \mathrm{l}$ saline. At $1300 \mathrm{~h}$, three hours after the last injection, the animals were killed and trunk blood, pituitary and hypothalamus were removed and stored until hormone assays were carried out. The thymus and spleen were dissected and weighed.

Serum concentrations of glucose were measured with a commercial kit from Boehringer Mannheim (Barcelona, Spain).

\section{Hormone determination}

Serum IGF-I concentrations were measured by a doubleantibody RIA (Daughaday et al. 1980). The IGF-I antiserum (UB2-495) was a gift from Drs Underwood and Van Wik, and distributed by the Hormone Distribution Program of NIDDK through the National Hormone and Pituitary Program (University of Maryland, School 


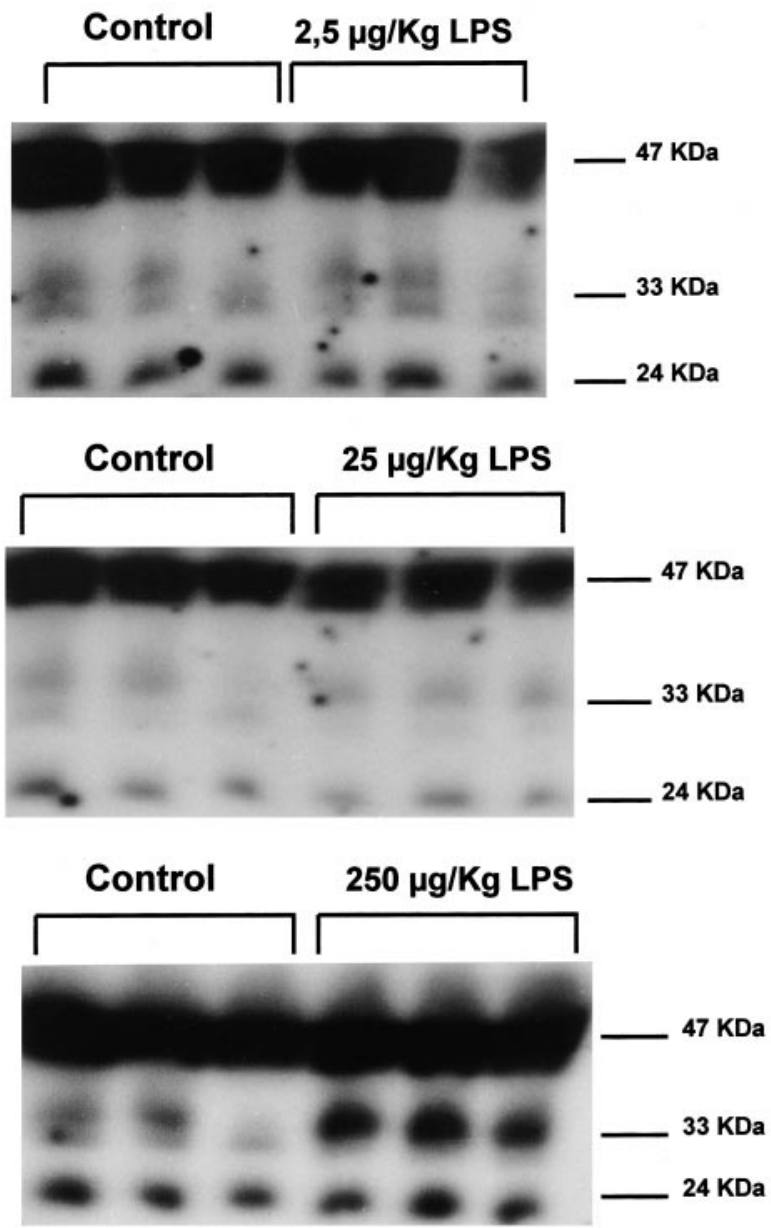

Figure 3 A representative Western ligand blot of IGFBPs in $2 \mu$ l serum from rats injected with different doses of LPS or saline three hours before being killed. IGFPBs were separated by a $12.5 \%$ SDS-PAGE gel, transferred to nitrocellulose, ligand blotted with ${ }^{125}$ I-IGF-I, and visualized via autoradiography. Approximate molecular weight of each band is indicated on the right.

of Medicine, Baltimore, MD, USA). Levels of IGF-I were expressed in terms of IGF-I A52-EPD-186 standard (Eli Lilly \& Company, Indianapolis, USA). The intra-assay coefficient of variation was $8 \%$. Samples from one experiment were run in the same assay. To confirm the elimination of IGFBPs, extracted and non-extracted serum fractions were incubated with ${ }^{125} \mathrm{I}-\mathrm{IGF}-\mathrm{I}$ at $4{ }^{\circ} \mathrm{C}$ for $24 \mathrm{~h}$. The separation of bound and free tracers was carried out with dextran charcoal. Extracted fractions showed 98\% free IGF-I whereas non-extracted fractions showed only $42 \%$ free IGF-I.

Concentrations of GH were measured by a doubleantibody RIA using reagents kindly provided by Dr Parlow of the NIDDK's National Hormone and Pituitary Program. Levels of GH were expressed in terms of
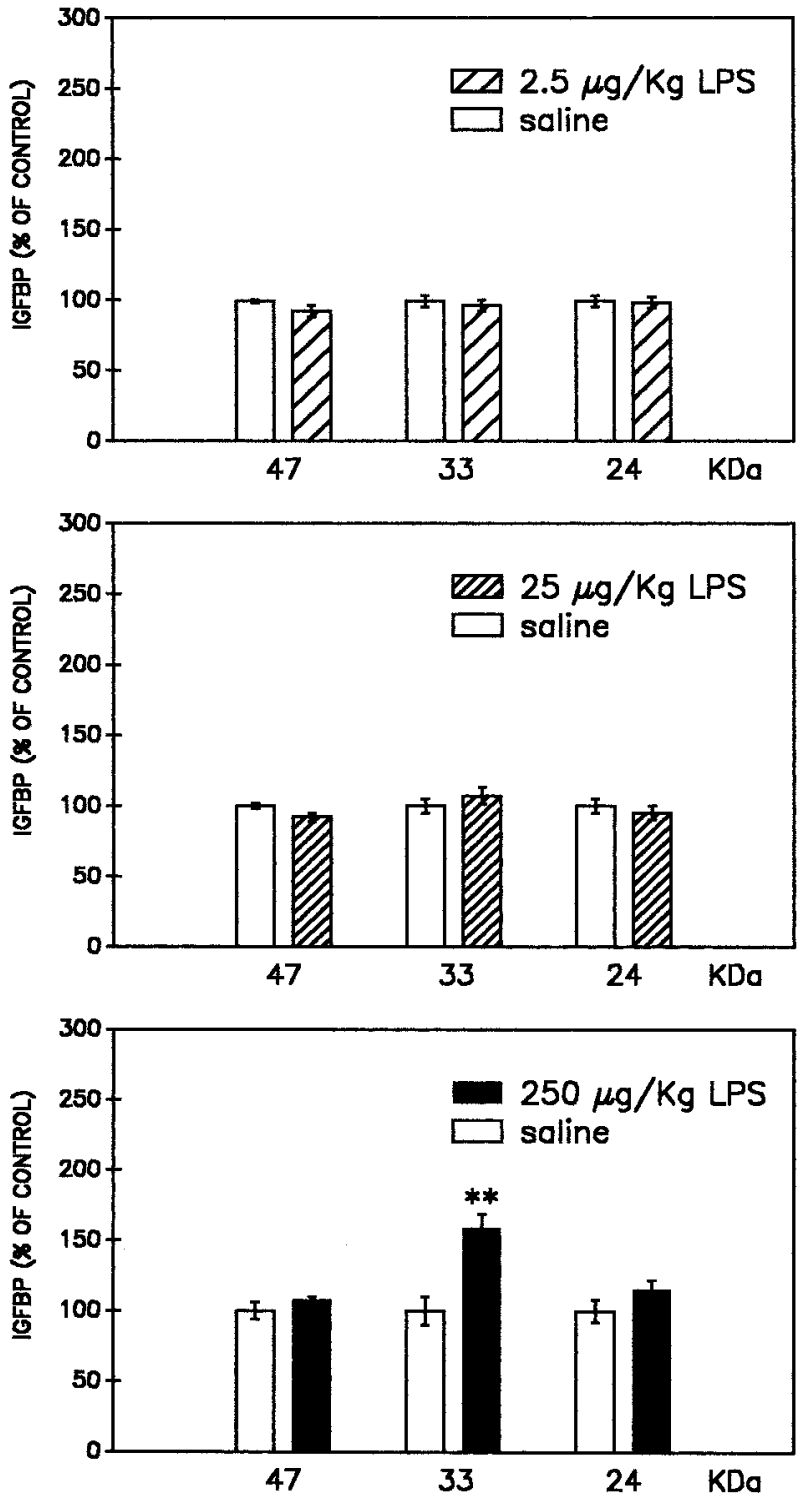

Figure 4 The effect of acute LPS administration on serum IGFBP. Data from 8 or 9 individual rats were quantified by densitometry and expressed as a percentage of the mean value in control rats treated with saline. ${ }^{* *} P<0 \cdot 01$ vs saline group (Student's $t$-test).

NIDDK rat-GH-RP-2 standard. The GH detection level was $10 \mathrm{pg}$, and the intra-assay coefficient of variation was $3 \%$. All necessary comparisons between test and control animals were made within one assay run.

Hypothalamic somatostatin content and serum insulin were measured by radioimmunoassays previously described (Tamarit-Rodriguez et al. 1985, Vara \& TamaritRodriguez 1988). Serum concentrations of corticosterone were determined by a competitive protein-binding assay (Millán et al. 1996). 

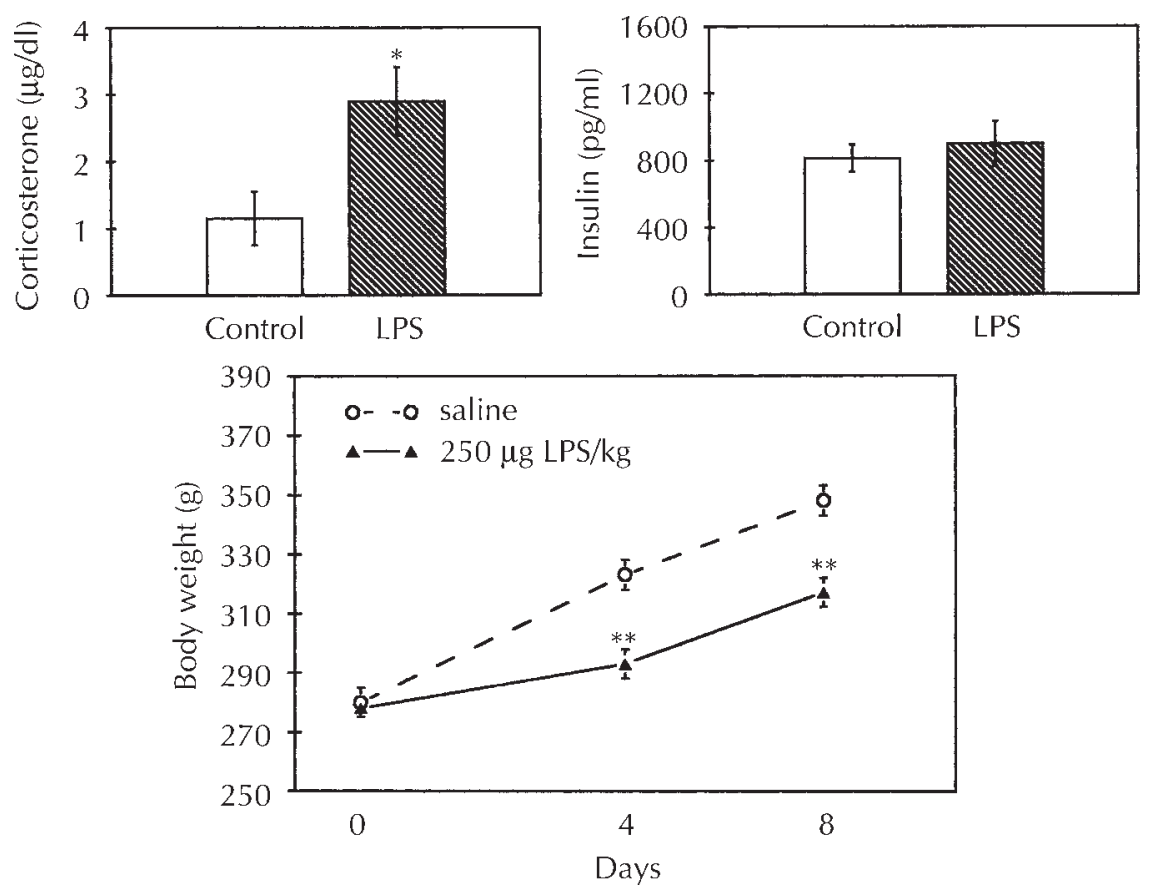

Figure 5 Effect of treatment with $250 \mu \mathrm{g} / \mathrm{kg}$ LPS for 8 days on serum concentrations of corticosterone and insulin and on body weight. Values are means \pm S.E.M. for at least 9 rats per group. ${ }^{*} P<0 \cdot 05$ vs control group, ${ }^{* *} P<0 \cdot 01$ vs saline group (Student's $t$-test).

\section{Western ligand blot of IGFBPS}

Western blots were prepared as previously described (Hossenlopp et al. 1986). Two microliters sera were diluted in sample buffer, boiled for 2 min at $100{ }^{\circ} \mathrm{C}$, and submitted to electrophoresis on $1 \%$ SDS-12.5\% acrylamide gels under nonreducing conditions. Prestained molecular weight standards (Bio-Rad, CA, USA) were run in parallel lanes. Following electrophoresis, proteins were transferred onto nitrocellulose sheets (Hybond-C extra, Amersham International, Amersham, Bucks, UK) using a semi-dry electrophoretic transfer cell (Bio-Rad). After transfer, the nitrocellulose sheets were dried and blocked for $1 \mathrm{~h}$ with $5 \%$ non-fat dry milk, $0 \cdot 1 \%$ Tween (Sigma) in Tris-buffered saline. The nitrocellulose membranes were incubated overnight at $4{ }^{\circ} \mathrm{C}$ with ${ }^{125}$ I-labeled IGF-I $\left(5 \times 10^{5}\right.$ c.p.m. $\left./ \mathrm{ml}\right)$. The nitrocellulose sheets were washed, dried and blots were exposed at $-80{ }^{\circ} \mathrm{C}$ to X-ray

Table 1 Effect of LPS administration $(250 \mu \mathrm{g} / \mathrm{kg})$ over 8 days on the relative spleen, thymus and adrenal weights. Values are means \pm S.E.M.

\begin{tabular}{|c|c|c|c|}
\hline & $\begin{array}{l}\text { Spleen } \\
\text { (mg/100 g) }\end{array}$ & $\begin{array}{l}\text { Thymus } \\
\text { (mg/100 g) }\end{array}$ & $\begin{array}{l}\text { Adrenal } \\
(\mathrm{mg} / 100 \mathrm{~g})\end{array}$ \\
\hline Saline $(n=10)$ & $337 \pm 12$ & $154 \pm 9 \cdot 4$ & $17 \cdot 8 \pm 0 \cdot 4$ \\
\hline LPS $(n=10)$ & $550 \pm 20^{* *}$ & $157 \pm 8$ & $20 \cdot 4 \pm 0 \cdot 72^{* *}$ \\
\hline
\end{tabular}

${ }^{* *} P<0 \cdot 01$ compared with saline group (Student's $t$-test) film (Kodak X-Omat AR, Eastman Kodak, Rochester, NY, USA) and two intensifying screens for 1-3 days according to the signal obtained. Autoradiographs were analyzed by densitometric scanning using a PC-Image VGA24 program for Windows. To obtain semiquantitative data for statistical analysis two gels were run, with 5 serum samples from one dosage of LPS and 4 control samples in each gel. The density of the IGFBP bands in each lane was expressed as the percentage of the mean density of control sera.

\section{Statistical analysis}

All data are presented as the mean \pm S.E.M. Simple linear regression was used to determine dose-related responses to treatments. Comparisons between means were made by one-way analysis of variance and subsequent Duncan's multiple range test. Comparisons between two groups were performed using Student's $t$-test. Significance was assumed when $P<0 \cdot 05$. GH data were subjected to $\log$ transformation since variances showed a log-normal distribution.

\section{Results}

Acute LPS administration decreased serum concentration of $\mathrm{GH}$ in a dose-dependent manner $\left(\mathrm{F}_{1,36}=6 \cdot 4, P<0 \cdot 05\right.$, 

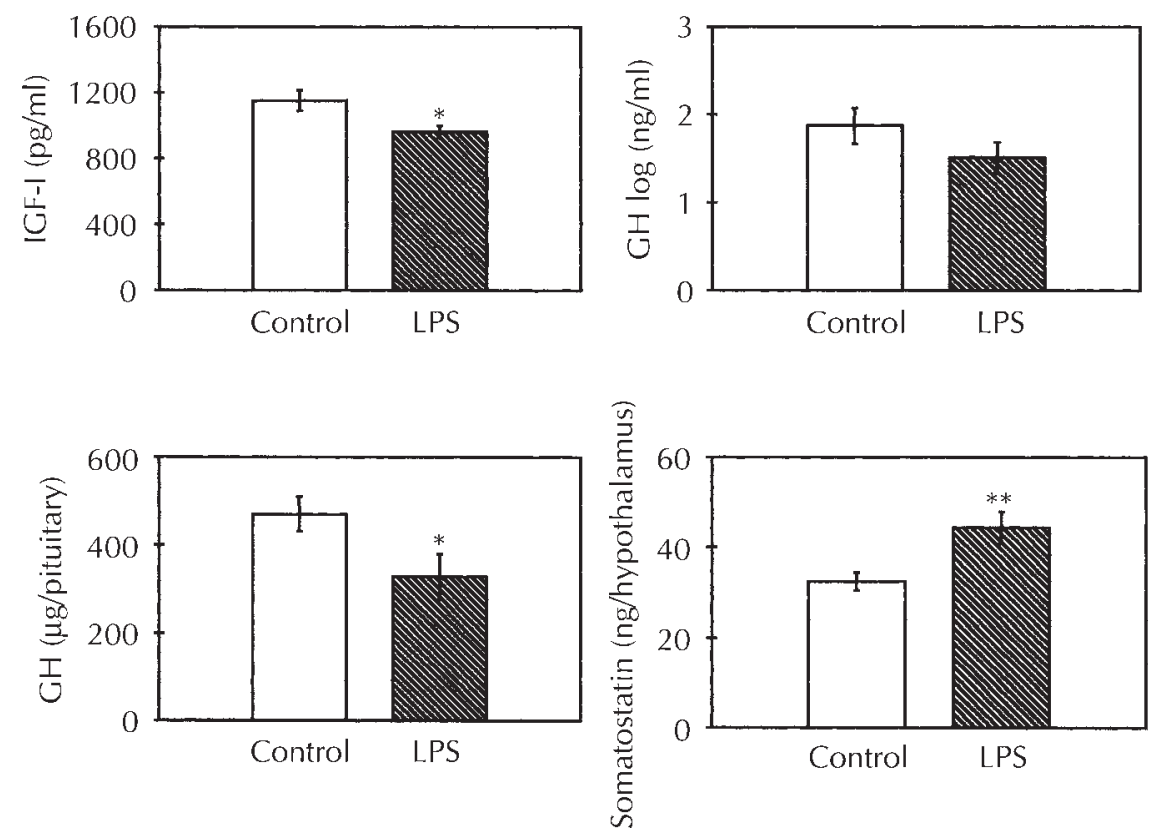

Figure 6 Effect of LPS administration for 8 days on serum concentrations of IGF-I, GH, pituitary $\mathrm{GH}$ content and hypothalamic somatostatin content. Values are means \pm S.E.M. for at least 9 rats per group. ${ }^{*} P<0 \cdot 05,{ }^{* *} P<0 \cdot 01$ vs control group (Student's $t$-test).

Fig. 1). Serum concentrations of both IGF-I and insulin were also decreased in rats which received 25 and $250 \mu \mathrm{g} /$ $\mathrm{kg}$ LPS $(P<0 \cdot 05$, Figs 1 and 2$)$. However, serum concentrations of glucose were not modified $3 \mathrm{~h}$ after LPS administration $(6 \cdot 6 \pm 0 \cdot 23 \mathrm{mM}$ in the control group compared with $6.5 \pm 0.25$ and $6 \cdot 4 \pm 0.38$ in the rats that received 25 and $250 \mu \mathrm{g} / \mathrm{kg}$ LPS respectively). In contrast, serum corticosterone levels increased depending on the dose $\left(F_{1,36}=17 \cdot 8, P<0 \cdot 01\right.$, Fig. 2). Pituitary $G H$ and hypothalamic somatostatin contents were not significantly modified $3 \mathrm{~h}$ after a single LPS injection (data not shown).

Western ligand blot of rat serum IGFBP showed a major band of $47 \mathrm{kDa}$ corresponding to IGFBP-3, a $33 \mathrm{kDa}$ band which most likely represents IGFBP-1 and IGFBP-2, and a $24 \mathrm{kDa}$ band identified as IGFBP-4 (Fig. 3). The densitometric quantification (Fig. 4) showed an increase in serum IGFBP-1 and IGFBP-2 in the rats that received an LPS injection of $250 \mu \mathrm{g} / \mathrm{kg}$, whereas no modifications in the IGFBPs were observed in the rats injected with 25 or $2.5 \mu \mathrm{g} / \mathrm{kg}$ LPS.

Since IL-1 or LPS treatments have been shown to induce anorexia, we examined body weight on days 4 and 8 of LPS treatment. As shown in Fig. 5, body weight was decreased in the rats treated with $250 \mu \mathrm{g} / \mathrm{kg}$ LPS $(P<0 \cdot 01)$, whereas, spleen and adrenal weight were significantly increased $(P<0 \cdot 01)$ and thymus weight was not modified by chronic LPS administration (Table 1 ).

Administration of $250 \mu \mathrm{g} / \mathrm{kg}$ LPS for 8 days did not modify serum insulin levels, but resulted in an increase in both serum concentration of corticosterone $(P<0 \cdot 05)$ (Fig.
5) and in adrenal weight $(P<0 \cdot 01)$ (Table 1). Although serum GH was not significantly modified by chronic LPS treatment, pituitary GH content and serum concentration of IGF-I were significantly decreased $(P<0 \cdot 05)$ (Fig. 6), whereas hypothalamic somatostatin content was increased in LPS-treated rats $(P<0 \cdot 01)$. As shown in Fig. 7 , rats treated chronically with LPS showed a significant increase in the three IGFBP bands identified by ligand blot in serum. This increase does not seem to be due to hemodynamic alterations, since serum concentrations of proteins were not modified by chronic LPS treatment $(51 \pm 1.06 \mathrm{~g} / 1$ in the control group compared with $49 \cdot 5 \pm 1 \cdot 7 \mathrm{~g} / 1$ in the rats treated with LPS).

\section{Discussion}

As expected, $3 \mathrm{~h}$ after the first LPS injection a marked catabolic response was observed in serum hormones, with an increase in serum corticosterone together with a significant decrease in serum concentrations of insulin, IGF-I and GH. Acute LPS administration at the higher dose also modified the IGFBPs of low molecular weight, IGFBP-1 and IGFBP-2. The increase in these serum binding proteins is in accordance with other data previously described (Fan et al. 1994) and may be due to hepatic modifications, since a decrease in the hepatic IGF-I output and an increase in the hepatic release of IGFBP-1 and IGFBP-2 four hours after a single LPS injection have been described (Fan et al. 1995a). The 


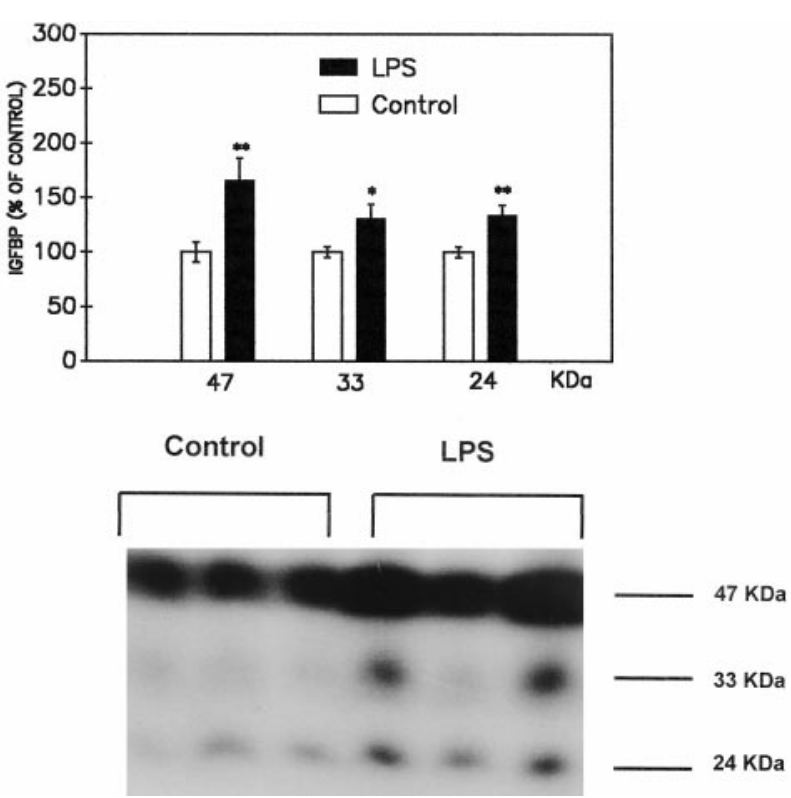

Figure 7 Effect of chronic LPS treatment on serum IGFBPs. The lower panel is a representative Western ligand binding of ${ }^{125}$ I-IGF-I to $2 \mu \mathrm{l}$ serum from LPS-treated and control rats treated with saline. Approximate molecular weights of each band are shown on the right. Densitometric measurements of bands from the Western ligand blot are shown as a percentage of controls (upper panel). Values are means \pm S.E.M. for at least 8 rats per group. ${ }^{*} P<0 \cdot 05$, ${ }^{* *} P<0 \cdot 01$ vs control group (Student's $t$-test).

increase in these IGFBPs might be secondary to the increased release of cytokines, since TNF and IL-6 induce hepatic IGFBP-1 production (Fan et al. 1995b, Samstein et al. 1996). Another possibility is that LPS-induced modifications in serum concentrations of insulin, IGF-I, GH and corticosterone stimulate hepatic IGFBPs synthesis, since corticosterone stimulates whereas insulin, IGF and GH inhibit the hepatic expression of the IGFBP1 gene (Ooi et al. 1990, Thissen et al. 1994). In our study insulin secretion was decreased after acute, but not during chronic LPS administration. Several alterations in carbohydrate metabolism have been described during acute endotoxemia, such as insulin resistance (Virkamaki \& Yki-Järvinen 1994), reduced or increased plasma insulin and increased secretion of glucagon (Yki-Järvinen et al. 1989, Bundz et al. 1995, Lang et al. 1996). However, insulin and glycemia alterations last only $2-3 \mathrm{~h}$.

The effect of chronic LPS treatment on serum concentrations of corticosterone and GH was notably less evident than the effect of acute administration of LPS. However, LPS administered at a dose of $250 \mu \mathrm{g} / \mathrm{kg}$ over 8 days significantly decreased body weight and increased the serum concentration of corticosterone. The different adrenal response to acute or chronic LPS administration can be explained by a tolerance phenomenon. Different data have been reported depending on the times of administration and the doses used - from a lowered to an almost absent adrenal response to LPS (Mefford et al. 1991, Mengozzi \& Ghezzi 1991, Hadid et al. 1995). The tolerance to chronic LPS administration seems to be related to decreased macrophage responsiveness to LPS, rather than to a decreased neuroendocrine response to cytokines (Mefford et al. 1991, Hadid et al. 1996).

In chronically LPS-treated rats, the decrease in serum IGF-I concentration is concomitant with an increase in the serum binding capacity of this hormone. Although it has been reported that IGFBP-3 is GH and IGF-I dependent (Spagnoli \& Rosenfeld 1997), acute LPS administration, in a higher dose than in the present study $(1 \mathrm{mg} / \mathrm{kg})$, increases hepatic IGFBP-3 levels together with a significant decrease in serum GH and IGF-I levels (Fan et al. 1994). These results suggest that other factors may modulate the serum concentration of IGFBP-3, and are in accordance with other data previously reported showing that IL-1, TNF and transforming growth factor (TGF- $\beta$ ) induce IGFBP-3 synthesis (Olney et al. 1995, Hembree et al. 1996, Han et al. 1997). Since LPS administration has been shown to increase not only IL-1 and TNF but also hepatic TGF $\beta$ mRNA levels (Masuhara 1995), these can be possible mechanisms by which LPS increases circulating IGFBP-3. Thus, the increase in IGFBP-3 levels may decrease the bioavailability of IGF-I in the peripheral tissues as has been shown in arthritic human cartilage (Neidel et al. 1997).

The mechanism by which chronic activation of the immune system inhibits the GH-IGF system is not well known. It has been postulated that the decrease in circulating IGF-I in response to infection may be caused by a direct effect of the cytokines IL-1 and/or TNF at the hepatocyte level (Thissen \& Verniers 1997), since TNF administration decreases circulating and hepatic IGF-I (Fan et al. 1995b). In our data, the difference in serum GH levels between the control group and the group receiving LPS for 8 days was not significant, but chronic LPS administration significantly decreased the serum concentration of IGF-I and the pituitary GH content. The decrease in both pituitary GH content and serum concentration of IGF-I suggests a decrease in pituitary GH secretion in LPS-treated rats. In fact, hypothalamic somatostatin content increased significantly in chronically LPStreated rats. An increase in somatostatin release induced by acute LPS treatment has been described both in vivo and in vitro (Fukata et al. 1985, Peisen et al. 1995). Furthermore, the suppression of $\mathrm{GH}$ secretion by acute endotoxin administration has been reversed by antisomatostatin serum (Kastin \& Martin 1982). These data suggest that the inhibitory effect of chronic LPS administration on the somatotropic axis can be mediated, at least in part, by an activation of the hypothalamic somatostatin release.

The effects of LPS on the neuroendocrine system seem to be mediated by the cytokines released by LPSstimulated macrophages and monocytes (Michalek et al. 
1980). It has recently been reported that the acute LPS-induced suppression of GH secretion is mediated by IL-1 $\beta$ and corticotropin releasing hormone (Peisen et al. 1995). However, another study showed that i.c.v. administration of IL-1 stimulated GH secretion (Rettori et al. 1987). In contrast, a continuous i.v. or i.c.v. administration of IL-1 $\beta$ and to a lesser extent IL- $1 \alpha$, inhibited GH secretion (Wada et al. 1995). These discrepancies may be due to the dosage, since other authors have described a biphasic effect of central IL-1 administration on GH secretion, with a stimulatory effect at low doses and an inhibitory effect at higher doses of IL-1 (Payne et al. 1992). In conclusion these data suggest that the catabolic state observed in chronic inflammation or endotoxic shock may be secondary to the decrease in GH and IGF-I secretion together with an increase in the circulating IGFBPs.

\section{Acknowledgements}

We thank Dr C Fernández Galaz from Cajal Institute of Madrid for her help in the setting-up of the IGFBP Western ligand blot. The authors are indebted to A Carmona for technical assistance. We are grateful to Lilly Spain for the IGF-I, and to the NIDDK National Hormone and Pituitary Program for the reagents for GH and IGF-I determinations. This work was supported by FIS grant no. 91/0133.

\section{References}

Besedovsky HO \& Del Rey A 1996 Immune-neuro-endocrine interactions: facts and hypotheses. Endocrine Reviews 17 64-102.

Besedovsky HO, Sorkin E, Keller M \& Muller J 1975 Changes in blood hormone levels during the immune response. Proceedings of the Society for Experimental Biology and Medicine 150 466-470.

Bundz S, Molina PE, Lang CH \& Abumrad NN 1995 Endogenous opiates do not modulate LPS-induced alterations in carbohydrate metabolism. Shock 4 397-402.

Dahn MS, Lange P \& Jacobs LA 1988 Insulin-like growth factor I production is inhibited in human sepsis. Archives Surgery 123 1409-1414.

Daughaday WH, Mariz IK \& Blethen SL 1980 Inhibition of access of bound somatomedin to membrane receptor and immunobinding sites: a comparison of radioreceptor and radioimmunoassay of somatomedin in native and acid-ethanol-extracted serum. Journal of Clinical Endocrinology and Metabolism 51 781-788.

Egdahl RH 1959 The differential response of the adrenal cortex and medulla to bacterial endotoxin. Journal of Clinical Investigation 38 921-929.

Elsasser TH, Caperna TJ \& Fayer R 1991 Tumor necrosis factor- $\alpha$ affects growth hormone secretion by a direct pituitary interaction. Proceedings of the Society for Experimental Biology and Medicine 198 547-554.

Fan J, Molina PE, Gelato MC \& Lang CH 1994 Differential tissue regulation of insulin-like growth factor-I content and binding proteins after endotoxin. Endocrinology 134 1685-1692.

Fan J, Char D, Kolasa AJ, Pan W, Maitra SR, Patlak CS, Spolarics Z, Gelato MC \& Lang CH 1995a Alterations in hepatic production and peripheral clearance of IGF-I after endotoxin. American Journal of Physiology 269 E33-E42.

Fan J, Char D, Bagby GJ, Gelato MC \& Lang CH 1995b Regulation of insulin-like growth factor-I (IGF-I) and IGF-binding proteins by tumor necrosis factor. American Journal of Physiology 269 1204-1212.

Fukata J, Kastin NW \& Martin JB 1985 Somatostatin release from the median eminence of unanesthetized rats: lack of correlation with pharmacologically suppressed growth hormone secretion. Neuroendocrinology 40 193-200.

Hadid R, Spinedi E, Daneva T, Grau G \& Gaillard RC 1995 Repeated endotoxin treatment decreases immune and hypothalamo-pituitary-adrenal axis responses: effects of orchidectomy and testosterone therapy. Neuroendocrinology 62 348-355.

Hadid R, Spinedi E, Giovambattista A, Chautard T \& Gaillard RC 1996 Decreased hypothalamo-pituitary-adrenal axis response to neuroendocrine challenge under repeated endotoxemia. Neuroimmunomodulation 3 62-68.

Han GR, Dohi DF, Lee HY, Rajah R, Walsh GL, Hong WK, Cohen P \& Kurie JM 1997 All-trans-retinoic acid increases transforming growth factor-beta2 and insulin-like growth factor binding protein-3 expression through a retinoic acid receptor-alpha-dependent signaling pathway. Journal of Biological Chemistry 272 13711-13716

Hembree JR, Pampusch MS, Yang F, Causey JL, Hathaway MR \& Dayton WR 1996 Cultured porcine myogenic cells produce insulin-like growth factor binding protein-3 (IGFBP-3) and transforming growth factor beta-1 stimulates IGFBP-3 production. Journal of Animal Science 74 1530-1540.

Hossenlop P, Seurin D, Segovia-Quinson B, Hardouin S \& Binoux M 1986 Analysis of serum insulin-like growth factor binding protein using western blotting: use of the method for titration of the binding proteins and competitive binding studies. Analytical Biochemistry 154 138-143.

Kastin NW \& Martin JB 1982 Altered release of growth hormone and thyrotropin induced by endotoxin in the rat. American Journal of Physiology 43 E332-E337.

Lang CH, Cooney R \& Vary TC 1996 Central interleukin-1 partially mediates endotoxin-induced changes in glucose metabolism. American Journal of Physiology 271 E309-E316.

López-Calderón A, González-Quijano MI, Tresguerres JAF \& Ariznavarreta C 1990 Role of LHRH in the gonadotropin response to restraint stress in intact male rats. Journal of Endocrinology $\mathbf{1 2 4}$ 241-246.

McCaffery T, Khosrow N, Lawrence A \& Kirsner J 1970 Severe growth retardation in children with inflammatory bowel disease. Pediatrics 45 386-393.

Madden KS \& Felten DL 1995 Experimental basis for neural-immune interactions. Physiological Reviews 75 77-106.

Masuhara M 1995 Expression of hepatocyte growth factor and transforming growth factor beta $1 \mathrm{mRNA}$ in $P$. acnes and lipopolysaccharide-treated rats. Journal of Gastroenterology 30 48-54.

Mefford IN, Master CF, Hepes MP \& Eskay RL 1991 Cytokine-induced activation on the neuroendocrine axis persists in endotoxin-tolerant mice. Brain Research 557 327-330.

Mengozzi M \& Ghezzi P 1991 Defective tolerance to toxic and metabolic effects of interleukin-1. Endocrinology 128 1668-1672.

Michalek SM, Moore RN, McGhee JR, Rosentreich DL \& Mergenhagen SE 1980 The primary role of lymphoreticular cells in the mediation of host responses to bacterial endotoxin. Journal of Infectious Diseases 141 55-63.

Millán S, González-Quijano MI, Giordano M, Soto L, Martín AI \& López-Calderón A 1996 Short and long restraint differentially affect humoral and cellular immune functions. Life Sciences 59 1431-1442.

Neidel J, Blum WF, Schaeffer, Schulze M, Schönau, Linschau J \& Föll J 1997 Elevated levels of insulin-like growth factor (IGF) 
binding protein-3 in rheumatoid arthritis synovial fluid inhibit stimulation by IGF-I of articular chondrocyte proteoglycan synthesis. Rheumatology International 17 29-37.

Olney RC, Wilson DM, Mohtai M, Fielder PJ \& Smith RL 1995 Interleukin-1 and tumor necrosis factor- $\alpha$ increase insulin-like growth factor-binding protein-3 (IGFBP-3) production and IGFBP-3 protease activity in human articular chondrocytes. Journal of Endocrinology 146 279-286.

Ooi GT, Orlowski CC, Brown AL, Becker RE, Unterman TG \& Rechler MM 1990 Different tissue distribution and hormonal regulation of messenger RNAs encoding rat insulin-like growth factor-binding proteins-1 and -2. Molecular Endocrinology 4 321-328.

Payne LC, Obal F \& Krueger JM 1992 Stimulation and inhibition of growth hormone secretion by interleukin-1 beta: the involvement of growth hormone-releasing hormone. Neuroendocrinology 56 118-123.

Peisen JN, McDonnell KJ, Mulroney SE \& Lumpkin MD 1995 Endotoxin-induced suppression of the somatotropic axis is mediated by interleukin- $1 \beta$ and corticotropin-releasing factor in the juvenile rat. Endocrinology 136 3378-3390.

Pinchot GB, Close VP \& Long CNH 1949 Adrenal changes produced in rats by infection with $B$. turalense and B. coli. Endocrinology 45 135-142.

Rettori V, Jurcovicova J \& McCann SM 1987 Central action of interleukin-1 in altering the release of TSH, growth hormone and prolactin in the male rat. Journal of Neuroscience Research $\mathbf{1 8}$ 179-183.

Rettori V, Milenkovic L, Beutler BA \& McCann SM 1989 Hypothalamic action of cachectin to alter pituitary hormone release. Brain Research Bulletin 23 471-475.

Samstein B, Holmes ML, Fan J, Frost RA, Gelato MC \& Lang CH 1996 IL-6 stimulation of IGFBP-1 production. Biochemical and Biophysical Research Communications 228 611-615.

Spagnoli A \& Rosenfeld RG 1997 Insulin-like growth factor binding proteins. Current Opinion in Endocrinology and Diabetes 4 1-9.
Tamarit-Rodriguez J, Vara E \& Tamarit J 1985 Antigenic specificity of a new and potent somatostatin antiserum. Hormone and Metabolism Research 17 623-625.

Thissen JP \& Verniers J 1997 Inhibition by interleukin-1 $\beta$ and tumor necrosis factor- $\alpha$ of the insulin-like growth factor-I messenger ribonucleic acid response to growth hormone in rat hepatocyte culture. Endocrinology 138 1078-1084.

Thissen JP, Pucilowska JB \& Underwood LE 1994 Differential regulation of insulin-like growth factor-I (IGF-I) and IGF binding protein-1 messenger ribonucleic acids by amino acid availability and growth hormone in rat hepatocyte primary cultures. Endocrinology 134 1570-1576.

Vara E \& Tamarit-Rodriguez J 1988 Islet secretion of immunoreactive thyrotropin-releasing hormone and the 'paracrine-like' effects of its exogenous administration. Acta Endocrinologica 118 429-436.

Virkamaki A \& Yki-Järvinen H 1994 Mechanism of insulin resistance during acute endotoxemia. Endocrinology 134 2072-2078.

Wada Y, Sato M, Niimi M, Tamaki M, Ishida T \& Takahara J 1995 Inhibitory effects of interleukin-1 on growth hormone secretion in conscious male rats. Endocrinology 136 3936-3941.

Walton PE \& Cronin MJ 1989 Tumor necrosis factor-alpha inhibits growth hormone secretion from cultured anterior pituitary cells. Endocrinology 125 925-929.

Yki-Järvinen H, Sammalkorpi K, Koivisto VA \& Nikkilä EA 1989 Severity, duration, and mechanism of insulin resistance during acute infection. Journal of Clinical Endocrinology and Metabolism 69 $317-323$.

Received 7 August 1997

Revised manuscript received 5 February 1998

Final version received 14 May 1998

Accepted 17 June 1998 